IWONA CHRZANOWSKA

Uniwersytet im. Adama Mickiewicza

w Poznaniu

\title{
EDUKACJA WŁĄCZAJĄCA \\ NA ETAPIE PRZEDSZKOLNYM W POLSCE - FAKTY I REFLEKSJE DLA PRZYSZŁYCH DZIAŁAŃ
}

ABSTRACT. Chrzanowska Iwona, Edukacja właczająca na etapie przedszkolnym w Polsce - fakty i refleksje dla przysztych dziatań [Preschool Inclusive Education in Poland - Facts and Reflections for Future]. Studia Edukacyjne nr 37, 2015, Poznań 2015, pp. 33-46. Adam Mickiewicz University Press. ISBN 978-83-232-2967-4. ISSN 1233-6688. DOI: $10.14746 /$ se.2015.37.3

In Poland, as in many other countries, inclusive education of children with disabilities start at the stage of pre-school education. Contemporary indicators on inclusive education of children with disabilities at the stage of pre-school education are optimistic. The last analysis $(2014,2015)$ shows that the rate of participation children with disabilities in pre-school education is $75 \%$. Indicators are lower in the countryside, higher in the big cities $(67 \%$ and $88 \%$, respectively). Preschoolers with disabilities are usually in ordinary kindergartens (79.1\%), then in inclusive education $(17.2 \%)$ and in special pre-schools $(3.8 \%)$. The indicators are different in public and non-public pre-schools (respectively: $79.1 \%$ and $65.4 \% ; 17.2 \%$ and $25.9 \% ; 3.8 \%$ and $8.6 \%$ ). The main problem of inclusive education in Poland is the late diagnosis of disability. The great number of children with disabilities receive their first diagnosis at the age of 6-7, if we concentrate on sensory or movement disabilities and even later if the child has an intellectual disability. The article presents the state of preschool education of children with disabilities in Poland and the necessary courses of action in this field in the future.

Key words: inclusive education, pre-school education, disability

W Polsce, podobnie jak w wielu innych krajach, wspólne kształcenie dzieci z niepełnosprawnością i sprawnych rozpoczęło się od etapu edukacji przedszkolnej. Pierwszymi placówkami integracyjnymi w Polsce były właśnie oddziały przedszkolne. To w przedszkolach, jeszcze przed formalnym usankcjonowaniem tendencji włączających, podejmowano pionierskie inicjatywy, których celem było dążenie do zapewnienia dzieciom z niepełnosprawnością konstytucyjnego prawa do wyboru ścieżki kształcenia, prze- 
ciwdziałania wykluczeniu edukacyjnemu i społecznemu z uwagi na istniejącą niepełnosprawność. Od pierwszych tego typu inicjatyw minęły blisko cztery dekady. Warto zatem pokusić się o refleksje, a z nich wyciągnąć wnioski dotyczące koniecznych działań skoncentrowanych na przyszłość m.in. edukacji włączającej.

Warto w tym miejscu kilka zdań poświęcić kwestiom terminologicznym, które ogniskują się wokół rozróżnienia, inaczej - synonimicznego traktowania pojęć integracja i włączanie. $W$ tym kontekście konieczne jest jednak określenie płaszczyzny rozważań. Szeroka, społeczna perspektywa pozwala $\mathrm{z}$ pewnym uproszczeniem traktować je synonimicznie, zwłaszcza $\mathrm{w}$ odniesieniu do celu i skutku podejmowanych inicjatyw. W obu bowiem przypadkach chodzi o równe traktowanie, o tożsamość praw, jedność bez kategoryzowania, sprzeciw wobec selekcji, zwłaszcza koncentrującej się na brakach, deficytach, podkreślania nie tego co dzieli, a łączy. Takiemu podejściu przyświecają idee dostrzegające racjonalność i nieuchronność odmienności, odnajdywania w niej waloru, a nie przeszkody dla wspólnej bezkonfliktowej koegzystencji. Perspektywa węższa, ograniczona np. do systemowych działań edukacyjnych skłania do rozgraniczenia pojęć. Opierając się choćby na dokumentach formalnoprawnych, czym innym jest klasa/oddział integracyjny czym innym wzorzec kształcenia w głównym nurcie (mainstream), czy tzw. edukacja włączająca. Skłoniło to wielu teoretyków, praktyków, jak i pracowników instytucji, w tym rządowych, do poszukiwania różnic między pojęciami. Niektórzy w prosty sposób, opierając się choćby na chronologii działań i decyzji, kształcenie w głównym nurcie uznali w Polsce za konsekwencję, kolejny etap działań systemowych czy bardziej zaawansowaną formę integracji. Nie jest to już jednak tak oczywiste, gdy przyjrzeć się doświadczeniom spoza rodzimego terenu. Zgodzić się należy z poglądami wskazującymi na zróżnicowanie modeli kształcenia osób z niepełnosprawnością na świecie z uwagi na m.in. uwarunkowania historyczne, prawne, geograficzne ${ }^{1}$, ale również kulturowe. Dlatego wśród różnych modeli mamy: propozycje kształcenia segregacyjnego (typowe np. dla Japonii czy Rosji), częściowo integracyjne (np. w Kanadzie, Hiszpanii, Niemczech, Australii) i w pełni integracyjne (np. w Anglii, USA, Szwecji, Danii, Austrii, czy we Włoszech). Nawet jednak $\mathrm{w}$ ramach poszczególnych kategorii różne są rozwiązania formalne i organizacyjne. Zazwyczaj również istotne znaczenie w procesie integracji odgrywa stopień niepełnosprawności, decydujący czy proces integracji obejmuje integrację poznawczą i społeczną czy jedynie spo-

${ }^{1}$ J. Kossewska, www.up.krakow.pl/biblio/pliki/kossewska_02.html, [dostęp: 26.10.2015]. 
łeczną lub wskazuje na większą skuteczność kształcenia segregacyjnego². $\mathrm{W}$ Polsce mamy do czynienia z koegzystencją trzech modeli: specjalnego, integracyjnego i ogólnodostępnego, choć coraz wyraźniej lansowany jest model tzw. pełnej integracji, czyli edukacji włączającej. Rozróżnienie pojęć integracja i włączanie $\mathrm{w}$ polskich warunkach wynika z różnic organizacyjnych poszczególnych modeli. $\mathrm{W}$ integracji mamy do czynienia $\mathrm{z}$ ograniczeniem liczby uczniów $\mathrm{z}$ zaburzeniami $\mathrm{w}$ rozwoju przypadających na klasę szkolną, z ograniczeniem całkowitej liczby uczniów w klasie, z podwójną obsadą pedagogiczną. $W$ przypadku włączania nie ma ograniczenia liczby uczniów z niepełnosprawnością i określenia górnego limitu uczniów w klasie (poza zdroworozsądkowym), nie ma podwójnej obsady, choć od 2016 r. szkoły będą miały nie tyle możliwość, co obowiązek zatrudnienia w szkole pedagoga wspierającego, pedagoga specjalisty, który będzie miał za zadanie wspierać uczniów z niepełnosprawnością $\mathrm{w}$ procesie uczenia się, a nauczycieli $\mathrm{w}$ procesie nauczania i kształcenia. $\mathrm{W}$ dalszym ciągu nie będzie to jednak sytuacja tak komfortowa jak w przypadku szkół/klas integracyjnych, w których podwójna obsada jest zagwarantowana dla każdej, bez wyjątku, klasy.

Nie ma wątpliwości, że współczesne dane dotyczące edukacji włączającej dzieci z niepełnosprawnością na etapie edukacji przedszkolnej per capita napawają optymizmem. $Z$ badań realizowanych przez IBE (opublikowanych w 2014 r.) wynika, że 75\% dzieci z niepełnosprawnością uczestniczy w edukacji przedszkolnej ${ }^{3}$. Jest to wskaźnik niemal identyczny jak w przypadku populacji ogólnej, uśredniony dla wszystkich grup wiekowych i wynosi $75,3 \%{ }^{4}$. Podobnie jak w populacji ogólnej istnieje duże zróżnicowanie udziału w edukacji przedszkolnej w zależności od miejsca zamieszkania. Najwięcej dzieci z niepełnosprawnością uczestniczy w edukacji przedszkolnej w miastach powyżej 500 tys. - 88\%, następnie w miastach od 20 do 100 tys. $82 \%$, miastach od 100 do 500 tys. $-80 \%$, miastach do 20 tys. $-72 \%$, najmniej niepełnosprawnych przedszkolaków jest na terenach wiejskich $-67 \% 5$.

2 Patrz piramidowy model kształcenia dzieci z niepełnosprawnością Deno 1970 - E. Deno, Special education and developmental capital, Exception Children, 1970, 37, s. 229-237.

${ }^{3}$ P. Grzelak, P. Kubicki, M. Orłowska, Realizacja badania ścieżek edukacyjnych niepetnosprawnych dzieci, uczniów i absolwentów. Raport końcowy, Warszawa 2014, s. 37.

${ }^{4}$ E. Falkowska, A. Telusiewicz-Pacak (red.), Dzieci w Polsce. Dane, liczby, statystyki, Warszawa 2013, s. 14.

5 Tamże, s. 38. 
Wskaźniki dla populacji ogólnej to $83,6 \%$ w przypadku miast i 51,2\% na terenach wiejskich ${ }^{6}$.

Prowadzone przez Piotra Grzelaka, Piotra Kubickiego i Martę Orłowską badania7 ${ }^{7}$ wskazują również, że zdecydowana większość dzieci z niepełnosprawnością uczęszcza do przedszkoli włączających. Jak wskazują wyniki badań, w placówkach publicznych $79,1 \%$ dzieci z niepełnosprawnością uczęszcza do przedszkoli ogólnodostępnych, 17,2\% - do integracyjnych i tylko 3,8\% - do specjalnych. Nieco inaczej wskaźniki przedstawiają się w przypadku placówek niepublicznych. Niższe są wskaźniki udziału dzieci $\mathrm{z}$ niepełnosprawnością $\mathrm{w}$ edukacji wspólnie z pełnosprawnymi rówieśnikami (65,4\% - ogólnodostępne i 25,9\% integracyjne), a wyższe w specjalnej $(8,6 \%)^{8}$.

Jak pokazują analizy, edukacja przedszkolna dzieci z niepełnosprawnością jest powiązana z poziomem wykształcenia rodziców. Dane wskazują, że im wyższe wykształcenie rodziców, tym wyższe wskaźniki udziału dzieci z niepełnosprawnością w edukacji przedszkolnej. Nie wiadomo jednak czy są one wynikiem wyższej świadomości, konieczności wczesnego objęcia dziecka edukacją i wsparciem specjalistycznym czy też może są np. związane $\mathrm{z}$ sytuacją społeczno-zawodową rodziców. Możliwe, że każde z tych uwarunkowań ma znaczenie dla podejmowanych decyzji. Faktem jest, że w edukacji przedszkolnej uczestniczy $90 \%$ dzieci rodziców z wyższym wykształceniem, a tylko $64 \%$ dzieci rodziców z wykształceniem podstawowym ${ }^{9}$.

Po części odpowiedzią na te pytania jest, uzyskana w badaniach IBE, wiedza dotycząca powodów nieposyłania dziecka z niepełnosprawnością do przedszkola. Najczęściej badani rodzice wskazywali, iż dziecko pozostaje w domu, gdyż ma zapewnioną opiekę (64,9\%). Nie rozstrzyga to jednak, czy rodzice postanawiający zatrzymać dziecko w domu uznają, że udział $\mathrm{w}$ edukacji przedszkolnej nie pełni istotnej roli $\mathrm{w}$ procesie rozwoju ich dziecka, czy może nie pozwalają na nią skromniejsze środki finansowe, np. w przypadku bezrobocia jednego z rodziców czy skromnych dochodów nawet w sytuacji pracy obojga rodziców. Autorzy raportu „Edukacja małych

${ }^{6}$ Tamże, s. 14.

$7 \mathrm{~W}$ badaniach przeprowadzonych w 1261 szkołach podstawowych i gimnazjach (specjalnych, integracyjnych i ogólnodostępnych, w których uczą się uczniowie z niepełnosprawnością z terenu całej Polski) brali udział dyrektorzy szkół i rodzice dzieci z niepełnosprawnością. W przypadku danych dotyczących edukacji przedszkolnej informacje pochodziły od badanych rodziców.

${ }^{8}$ E. Falkowska, A. Talusiewicz-Pacak (red.), Dzieci w Polsce, s. 41.

${ }^{9}$ Tamże, s. 38. 
dzieci..." (2010) ${ }^{10}$ stawiają tezę, że bieda może prowadzić do instrumentalizacji relacji rodzinnych. Dziecko w rodzinie biednej stanowi wartość, której rodzice nie chcą się pozbywać "oddając” je do przedszkola. Opieka nad nim dla bezrobotnej matki czy ojca może stanowić bufor chroniący przed poczuciem bezużyteczności, bezwartościowości, nieprzydatności. Wszystko to może prowadzić do przeświadczenia, że korzystanie z opieki przedszkolnej jest postrzegane $w$ kategoriach kosztów a nie korzyści.

Kolejny wskaźnik, na który zwrócono uwagę, informuje o brakach infrastrukturalnych. $22 \%$ rodziców uzasadniło nieuczęszczanie dziecka do przedszkola brakiem placówki/oddziału przedszkolnego w pobliżu miejsca zamieszkania. Istotnym powodem okazała się również niesatysfakcjonująca oferta, niezapewniająca odpowiedniego wsparcia (5,2\%). Niewielka, niemniej określona liczba rodziców spotkała się z odmową przyjęcia dziecka do przedszkola z uwagi na niepełnosprawność $(2,0 \%)^{11}$. Autorzy raportu interpretując $25 \%$ wskaźnik nieuczestniczenia dzieci z niepełnosprawnością w edukacji przedszkolnej sugerują, że może on wynikać z przeświadczenia rodziców o możliwości, ale i konieczności zapewnienia dziecku opieki $\mathrm{w}$ domu $\mathrm{w}$ zgodzie $\mathrm{z}$ tradycyjnym podejściem do wychowania. Nie można jednak wykluczyć, jak wspomniałam wcześniej, że jest on przynajmniej po części efektem braku świadomości znaczenia wczesnego wsparcia rozwoju dziecka. Mogłoby to zatem dowodzić, że sama rodzina dziecka z niepełnosprawnością nie uzyskuje skutecznego wsparcia. Brakuje działań uświadamiających i przekonujących rodziców, jak ważne jest wczesne wspomaganie rozwoju, wczesna diagnoza, terapia i rehabilitacja. Jakie ma ona znaczenie dla możliwości uczestniczenia dziecka w obowiązkowej już edukacji w kontekście form kształcenia, jakie ma znaczenie dla społecznego rozwoju ich dziecka. Możliwe jest również, że niechęć rodziców posyłania dziecka z niepełnosprawnością do przedszkola jest efektem złych doświadczeń, braków i barier, z którymi spotkali się inni rodzice dzieci z niepełnosprawnością $\mathrm{w}$ tym zakresie.

Łatwo cieszyć się ze wskaźników globalnych 75\% udziału dzieci z niepełnosprawnością $\mathrm{w}$ edukacji przedszkolnej, tym bardziej że porównywalnych $\mathrm{z}$ analogicznymi w populacji ogólnej, jeśli przyjmować je bezrefleksyjnie. Znacznie trudniej, gdy uzmysłowimy sobie, że w przypadku dzieci $\mathrm{z}$ niepełnosprawnością powinny być one, logicznie rzecz biorąc, znacznie wyższe. Nie ma wątpliwości, że wczesne wspieranie rozwoju przynosi bardzo dobre efekty w przypadku każdego dziecka. Niemniej straty spowodo-

10 A. Giza (red.), Edukacja małego dziecka, standardy, bariery, szanse, Warszawa 2010, s. 22.

11 Tamże, s. 43. 
wane zaniechaniem oddziaływań w przypadku dzieci z niepełnosprawnością są znacznie poważniejsze niż w przypadku populacji osób sprawnych. Jedną z kluczowych konsekwencji jest np. opóźniona diagnoza zaburzeń rozwojowych i wszelkie jej konsekwencje tak w wymiarze indywidualnym, jak i społecznym, z określonym wzorcem postaw wobec niepełnosprawności i osoby z niepełnosprawnością włącznie.

W Polsce problemem jest wciąż zbyt późny wiek diagnozy niepełnosprawności ${ }^{12}$. W przypadku osób z niepełnosprawnością intelektualną lekkiego stopnia największa grupa dzieci uzyskuje diagnozy w wieku 6-11 lat odpowiednio: 6 lat - 11\%, $7-15 \%, 8-12 \%, 9-8 \%, 10-10 \%, 11-8 \%$. 18\% dzieci uzyskuje diagnozę do 5 roku życia tyle samo od 12 do 16 roku życia. Głębsze stopnie niepełnosprawności intelektualnej: umiarkowanego i znacznego stopnia najczęściej diagnozowane są do 2 roku życia (41\%), niemniej diagnoza niepełnosprawności po 5 roku życia to rzeczywistość około $34 \%$ dzieci z niepełnosprawnością intelektualną umiarkowanego lub znacznego stopnia ${ }^{13}$. Analizy prowadzone $w$ tej samej kwestii, ale dotyczące dzieci z ASD wskazują, że do 3 roku życia diagnozę ma jedynie $12 \%$ dzieci. Najczęściej diagnoza formułowana jest w wieku 3 lat - 16\%, 4 -14\% i 6 lat $13 \%$. Bardzo duża grupa (38\%) uzyskuje diagnozę w wieku od 7 do 15 roku życia ${ }^{14}$.

Pozostałe kategorie wyróżnione przez rodziców jako powody nieposyłania dziecka do przedszkola nie pozostawiają wątpliwości, iż związane są z niewydolnością i niedoskonałością systemu. Wciąż sieć placówek/ oddziałów/punktów przedszkolnych nie zapewnia dzieciom w Polsce równych szans $\mathrm{w}$ dostępie do kształcenia. $\mathrm{W}$ dalszym ciągu, mimo blisko czterdziestoletnich doświadczeń integracyjnych praktyk, dzieci z niepełnosprawnością spotykają się z wykluczeniem z uwagi na niepełnosprawność lub nieumiejętność ich wsparcia w procesie rozwoju. Niestety, zazwyczaj niewielkie, jak w tym przypadku, wskaźniki są bagatelizowane. Przegrywają wizerunkowo z ogólnym dobrym czy nawet bardzo dobrym wynikiem. Nie należy jednak zapominać, że za każdym z owych $25 \%$ przypadków dzieci z niepełnosprawnością nieuczęszczających do przedszkoli kryje się konkretna rodzina i konkretne dziecko, które powinno być wspierane, któremu stworzenie najlepszych, a nie tylko optymalnych, warunków jest w XXI wieku prawem, obowiązkiem, a nie tylko przywilejem.

Przeświadczenia rodziców, zwłaszcza w kontekście ostatnich z wymienionych kategorii, znajdują potwierdzenie $w$ powodach odmowy przyjęcia

\footnotetext{
${ }^{12}$ Na problem zwracał uwagę jeszcze w latach 90. XX wieku m.in. Jan Pańczyk.

${ }^{13}$ A. Giza (red.), Edukacja małego dziecka, s. 33.

14 Tamże, s. 34.
} 
dziecka do przedszkola, jakie uzyskano od dyrektorów placówek. Najczęściej wymieniano wśród nich: prognozę niepowodzenia („,dziecko sobie nie poradzi w przedszkolu") - 23,2\%, specjalizację w obrębie niepełnosprawności („nie pracujemy z takimi niepełnosprawnościami”) - 19,7\%, brak specjalistów - 14,3\%, nastawienie na dzieci bez niepełnosprawności („nie pracujemy z dziećmi z niepełnosprawnością") - 10,8\%, bariery architektoniczne $6,5 \%$, brak zgody rodziców dzieci sprawnych $-4,4 \% 15$. Ponownie można dane te przedstawić jako incydentalne (jak interpretują to autorzy badań), jednak można potraktować je jako szczególnie niebezpieczne, bo: pogłębiające poczucie odrzucenia i wykluczenia, z którym nie każda rodzina z dzieckiem z niepełnosprawnością będzie potrafiła sobie poradzić; przyzwolenie na łamanie prawa i bezkarność tych, którzy powinni stać na jego straży.

$\mathrm{Z}$ analiz wynika, że najczęściej niepełnosprawnym przedszkolakiem jest dziecko z ASD (85\%), dalej niesłyszące (84\%), słabosłyszące z niepełnosprawnością ruchową i z niepełnosprawnością intelektualną umiarkowanego lub znacznego stopnia (79\%), najrzadziej dziecko niewidome i słabowidzące (odpowiednio 66\% i 70\%) ${ }^{16}$.

Jednym z problemów edukacji osób z niepełnosprawnością w głównej mierze związanych z etapem edukacji przedszkolnej jest nieefektywność systemu orzekania o niepełnosprawności. Wyraża się on poza powodami wskazanymi wcześniej m.in. brakiem rzetelnej diagnozy, nieprzyjaznymi zasadami diagnozowania, co może prowadzić do wydawania nieobiektywnych diagnoz (np. pod naciskiem rodzica). Ponadto, w poradniach publicznych brakuje specjalistów, co wydłuża czas oczekiwania na diagnozę, wizyty u orzeczników są krótkie, co sprawia wrażenie, że orzecznik nie ma wystarczającej ilości czasu na przeprowadzenie rzetelnej diagnozy, niepełne diagnozy mogą z kolei prowadzić do podejmowania niewłaściwych decyzji edukacyjnych, dziecko trafia do nieodpowiedniej placówki, nie otrzymuje właściwie dostosowanej do swoich potrzeb pomocy. Dotyczy to zwłaszcza osób z niepełnosprawnościami sprzężonymi, choć ma miejsce również w przypadku innych niepełnosprawności ${ }^{17}$.

Być może z tego powodu tylko 35\% dzieci z niepełnosprawnością uczęszcza do przedszkola przez cały okres ustawowo możliwego wymiaru trzech lat. Średnio około 19\% dzieci spędza w przedszkolu 2 lata, około $21 \%$ - rok ${ }^{18}$.

15 Tamże, s. 43.

16 Tamże, s. 39.

${ }_{17}$ M. Sochacka-Kawiecka i in., Właczajacy system edukacji i rynku pracy - rekomendacje dla polityki publicznej. Raport końcowy, Warszawa 2015, s. 89.

18 Tamże, s. 37. 
Nieco mniej niż u połowy $(47,3 \%)$ dzieci z niepełnosprawnością podjęta została decyzja o zmianie przedszkola. Zdecydowanie częściej w przypadku przedszkoli publicznych niż niepublicznych, w obu jednak przypadkach najczęściej dotyczyła rezygnacji z edukacji dziecka w przedszkolu ogólnodostępnym $(62 \%$ z przedszkoli ogólnodostępnych publicznych i $7,5 \%$ z niepublicznych, $22,6 \% \mathrm{z}$ integracyjnych przedszkoli publicznych i $0,5 \% \mathrm{z}$ niepublicznych, $6,8 \%$ z przedszkoli specjalnych publicznych i $0,6 \%$ $\mathrm{z}$ niepublicznych ${ }^{19}$ ).

Główne powody zmiany przedszkola to: przeniesienie do przedszkola, które miało opinię lepiej przystosowanego do potrzeb dziecka $(19,9 \%)$, zmiana miejsca zamieszkania $(18,5 \%)$, brak potrzebnego wsparcia $(11,9 \%)$, złe relacje z rówieśnikami $(10,9 \%)$, sugestia pracowników przedszkola $(7,0 \%)^{20}$.

Niewiele istnieje doniesień $\mathrm{z}$ badań realizowanych $\mathrm{w}$ kontekście udziału $\mathrm{w}$ edukacji przedszkolnej dzieci z uwzględnieniem stopnia niepełnosprawności. Ciekawych wyników na temat dostarcza badanie przeprowadzone $\mathrm{w}$ tym zakresie $\mathrm{w}$ grupie dzieci $\mathrm{z}$ głębokimi, wielorakimi niepełnosprawnościami, zrealizowane $\mathrm{W}$ województwie lubelskim ${ }^{21}$. W badaniu uczestniczyło 200 rodzin $\mathrm{z}$ dzieckiem głęboko wielorako niepełnosprawnym do 7 roku życia (w których łącznie wychowuje się 208 dzieci z niepełnosprawnością, średnia wieku dzieci wyniosła 4,5 roku) ${ }^{22}$. Analizy pozwoliły wskazać, że około $67 \%$ dzieci uczęszcza do przedszkoli lub punktów przedszkolnych. Największa grupa dzieci uczęszcza do przedszkoli specjalnych (ok. 37\%), niewiele jednak mniejsze są liczebności dzieci uczęszczających do przedszkoli integracyjnych i ogólnodostępnych $(31,6 \%)$. Żadne z dzieci nie uczęszczało wcześniej do żłobka. Najbliżej miejsca zamieszkania dziecka znajdują się przedszkola ogólnodostępne, następnie integracyjne, a najdalej położone od miejsca zamieszkania są przedszkola specjalne. $\mathrm{W}$ przypadku dzieci głęboko wielorako niepełnosprawnych należy się spodziewać, że najlepszą, najbardziej dopasowaną ofertą będą przedszkola specjalne. Z przeprowadzonych analiz wynika, że w małych miasteczkach i na terenach wiejskich dominują przedszkola ogólnodostępne, uczęszcza do nich około $46 \%$

19 Tamże, s. 41.

20 Tamże, s. 42.

${ }^{21} \mathrm{~W}$. Otrębski i in., Wspieranie rodzin z niepetnosprawnym dzieckiem wyzwaniem dla pracy socjalnej. Badania rodzin z niepetnosprawnymi dziećmi w województwie lubelskim, Lublin 2011.

22 Tamże, s. 89. 
dzieci z niepełnosprawnością, podczas gdy w Lublinie $50 \%$ z głębokimi wielorakimi niepełnosprawnościami znajduje się w przedszkolach specjalnych. Im większa miejscowość, tym większy odsetek udziału w edukacji przedszkolnej dzieci z głęboką wieloraką niepełnosprawnością. Wskaźnik udziału dzieci $\mathrm{w}$ edukacji $\mathrm{w}$ przedszkolu ogólnodostępnym jest tym wyższy, im mniejszą miejscowość zamieszkują. W przypadku przedszkoli integracyjnych i specjalnych tendencja jest odwrotna - im większa miejscowość, tym większe wskaźniki udziału w edukacji przedszkolnej w każdej z form, przy czym wskaźniki są wyraźnie wyższe w przypadku przedszkoli specjalnych niż integracyjnych ${ }^{23}$. Dzieci z głęboką wieloraką niepełnosprawnością powinny korzystać z szeregu innych form specjalistycznego wsparcia. Analizy wskazały, że zamieszkiwanie w mniejszej miejscowości w znacznym stopniu możliwości te ogranicza. Generalnie największa liczba dzieci korzysta z zajęć rehabilitacyjno-edukacyjnych (52,4\%), następnie logopedycznych $(47,6 \%)$, rehabilitacji fizjoterapeutycznej $(26,9 \%)$. Tylko w przypadku zajęć rehabilitacyjno-edukacyjnych miejsce zamieszkania $w$ zasadzie nie różnicuje grupy $\mathrm{w}$ tym zakresie, jednak już korzystanie $\mathrm{z}$ rehabilitacji fizjoterapeutycznej wyraźnie uzależnione jest od wielkości miejscowości. Im miejscowość mniejsza, tym rzadszy udział dziecka w specjalistycznych zajęciach ${ }^{24}$. Autorzy badania zwracają również uwagę na status zawodowy rodziców dzieci z głęboką wieloraką niepełnosprawnością, opisując ją jako znacznie gorszą niż w populacji ogólnej. Okazuje się bowiem, że aż ponad 52\% kobiet jest bezrobotnych (niespełna $17 \%$ mężczyzn) ${ }^{25}$. Analizy ujawniają jednocześnie, że na wskaźniki nie ma wpływu fakt uczęszczania/nieuczęszczania dziecka do przedszkola. Są natomiast nimi najprawdopodobniej możliwości znalezienia zatrudnienia, zwłaszcza poza rolnictwem na terenach wiejskich. Inną kwestią jest również fakt, że o ile bezrobotni mężczyźni szukają pracy, tak bezrobotne matki dzieci z głęboką wieloraką niepełnosprawnością pracy nie poszukują, tłumacząc to koniecznością opieki nad dzieckiem ${ }^{26}$. Wcale nie musi to oznaczać, że fakt nieposzukiwania pracy przez matki dzieci z niepełnosprawnością jest ich wyborem. Warto bowiem uświadomić sobie, że aktywność zawodowa obliguje zazwyczaj do 40 -godzinnego tygodnia pracy, czyli 8 godzin dziennie, co z dojazdem do i z pracy z dużym prawdopodobieństwem sięgać może 9 i więcej godzin każdego dnia. Tymczasem, jak wskazują autorzy badań, dziecko z niepełnosprawnością, tym bardziej głęboką i wieloraką, uczestniczy $\mathrm{w}$ zajęciach przedszkolnych $\mathrm{w}$ niewielkiej

\footnotetext{
23 Tamże, s. 150.

24 Tamże, s. 152.

25 Tamże, s. 158.

26 Tamże, s. 162.
} 
liczbie godzin dziennie. Dodatkowo zachodzi zazwyczaj (szczególnie w przypadku przedszkoli ogólnodostępnych) konieczność przebywania $\mathrm{w}$ przedszkolu rodzica razem $\mathrm{z}$ dzieckiem ${ }^{27}$. Często jest ona warunkiem przyjęcia dziecka do przedszkola.

Jako podsumowanie warto przedstawić wyniki analiz autorów Raportu „Edukacja małych dzieci, standardy, bariery, szanse” z 2010 roku, w którym wśród głównych barier wskazano na: zbyt wąskie rozumienie edukacji; ograniczenie dostępu i selektywność edukacji; brak otwartości i współpracy; niewystarczającą indywidualizację w podejściu do dziecka; przymus, schematyzm i nudę; świadectwo jako efekt edukacji oraz poczucie niepewności28.

Zbyt wąskie rozumienie edukacji oznacza sprowadzanie edukacji do murów placówek, w których się odbywa. W Polsce wciąż jeszcze pokutuje negatywny wizerunek żłobków i przedszkoli, uznawanych za „przechowalnie" dla dzieci, których rodzice muszą pracować. Po części jest on spuścizną poprzedniego ustroju, niestety również, jak twierdzą autorzy, wciąż nienajlepszej jakości współczesnych usług w tym zakresie. Przekłada się to na poczucie winy rodziców, z których wielu woli, by ich dzieci zostały w domu. Dla innych rodziców możliwość „oddania” dziecka do przedszkola (a później szkoły) staje się z kolei okazją do odsunięcia odpowiedzialności za jego wychowanie i edukację. Zazwyczaj jest również tak, że rodzice nieangażujący się $\mathrm{w}$ pracę nad rozwojem własnych dzieci we wczesnym okresie ich życia, nie będą tego czynili również później. Autorzy badań podkreślają coraz większą rolę ojców w wychowaniu dzieci, ale tendencja ta jest zauważalna głównie w rodzinach wielkomiejskich i dobrze wykształconych, rzadziej w innych środowiskach, które tradycyjnie opiekę nad małym dzieckiem cedują na matki ${ }^{29}$.

Nie jest doceniana edukacja pozainstytucjonalna, ale również nie przykłada się do niej zbyt dużej wagi w kontekście jej organizowania, promowania. Właściwie pozostawiana jest $\mathrm{w}$ gestii pomysłowości rodziców, nie zaś oferty, z której mogliby korzystać, na tyle różnorodnej, by zaspokoić szerokie potrzeby i zainteresowania dzieci i rodziców. W przypadku rodziców dzieci z niepełnosprawnością podnoszona jest kwestia braku miejsc, gdzie dzieci z niepełnosprawnością mogłyby spędzać czas ze swoimi rodzicami,

27 Tamże, s. 229.

${ }^{28}$ A. Giza (red.), Edukacja małego dziecka, s. 19.

${ }^{29}$ Tamże s. 20. 
ale jednocześnie wspólnie ze sprawnymi rówieśnikami (np. place zabaw dostosowane są zazwyczaj do możliwości dzieci sprawnych).

Ograniczenie dostępu i selektywność edukacji odnosi się do wielu kwestii, m.in. infrastrukturalnych, finansowych, mentalnych, wyrażających się w praktykach stygmatyzujących. Dotyczą one różnych grup dzieci - od niepełnosprawnych i defaworyzowanych, po wybitnie zdolne.

Brak otwartości i nastawienia na współpracę dotyczy nie tylko relacji nauczyciel - rodzic, ale również szkoła - inne instytucje. W pierwszym przypadku podkreślane są kwestie jakości relacji, umiejętności nawiązywania kontaktu, rozmawiania, zaufania, dzielenia się wiedzą i informacjami. $\mathrm{W}$ drugim problemem jest brak współpracy nawet $\mathrm{w}$ ramach instytucji z tego samego sektora. W przypadku dzieci z niepełnosprawnością, które są "pod opieką" różnych resortów (zdrowia, edukacji, opieki społecznej), przepływ informacji jeszcze bardziej „kuleje”. Dzielenie się informacjami na temat zdrowia, potrzeb, możliwości, potencjału, deficytów dziecka jest kwestią dobrej woli osób w nich pracujących, a tej często brakuje. Każdy kolejny etap kształcenia rozpoczyna się od poznawania ucznia, tak jakby nie miało ono żadnej przeszłości edukacyjnej, doświadczeń, sukcesów, porażek ${ }^{30}$. Inną, rzadko podnoszoną kwestią jest daleko posunięta specjalizacja w ramach poszczególnych placówek/instytucji, przez autorów Raportu określona jako - aspołeczność instytucji. Oznacza ni mniej ni więcej, jak bezrefleksyjne realizowanie narzuconych zadań. Miejski czy gminny ośrodek pomocy społecznej ogranicza się do kwestii związanych z zasadnością dystrybucji środków finansowych (wypłata zasiłków), przedszkole/szkoła - realizacji zadań opiekuńczych czy edukacyjnych, biblioteka - wypożyczania książek itp. Wszystkie one pracują na rzecz precyzyjnie zdefiniowanych beneficjentów i nie zadają sobie zazwyczaj trudu współpracy na rzecz jakości życia całej społeczności ${ }^{31}$.

W podejściu do dziecka, jak podkreślają badacze, wciąż brakuje nastawienia na indywidualizację, którego podstawą stałoby się poszukiwanie jego mocnych stron, wspieranie możliwości i umiejętności, kształtowanie poczucia własnej wartości, szacunek dla dziecka. Podnoszona jest również kwestia jakości kadry edukatorów, nastawienia na wyniki (sprawdzianów, egzaminów, świadectw), czy poczucia bezpieczeństwa w procesie edukacji, które sprowadzane jest najczęściej do bezpieczeństwa fizycznego, z pominięciem mentalnego, związanego z poczuciem wspólnoty, odnalezienia swojego miejsca we wspólnocie, szacunku dla wysiłku każdego z uczestników procesu edukacji (dzieci, rodziców, nauczycieli).

\footnotetext{
30 Tamże, s. 24.
}

31 Tamże, s. 22. 
$\mathrm{Z}$ danych Raportu na temat sytuacji niepełnosprawnych dzieci w przedszkolach i szkołach warszawskich Agnieszki Dudzińskiej wynika, że: placówki ogólnodostępne, w mniejszym stopniu również integracyjne, nie radzą sobie $\mathrm{z}$ zapewnieniem odpowiednich warunków uczniom $\mathrm{z}$ orzeczeniem o potrzebie kształcenia specjalnego. Skutkiem tego jest, jak twierdzi autorka, przesuwanie dzieci do innego typu placówek („w dół”), najczęściej wraz z końcem etapu edukacyjnego. Warszawskie przedszkola ogólnodostępne nie są $\mathrm{w}$ stanie zapewnić dzieciom ujawniającym zaburzenia $\mathrm{w}$ rozwoju potrzebnego im wsparcia na miejscu, głównie z uwagi na brak godzin dla specjalistów i dodatkowych pedagogów. Wciąż niewystarczająca, w stosun$\mathrm{ku}$ do potrzeb, jest liczba miejsc w przedszkolach integracyjnych. Dzieci z niepełnosprawnością często zmieniają przedszkola ${ }^{32}$. Nie sprzyja to integracji z grupą rówieśników. Zazwyczaj również powodem zmiany placówki są doznane przez dziecko niepowodzenia, co nie pozostaje bez konsekwencji dla budowania poczucia wartości dziecka, czy przynależności do grupy, pogłębia odczucie niedopasowania, odrzucenia, inności, a nawet bycia gorszym. Problemem są wciąż niesatysfakcjonujące relacje kadry pedagogicznej z rodzicami dzieci. Rodzice są np. obwiniani za zachowania dziecka, które interpretowane są jako błędy wychowawcze. Z uwagi na brak wsparcia dziecka w placówce, wielu rodziców przejmuje na siebie realizację zaleceń rehabilitacyjnych czy terapeutycznych, często $\mathrm{w}$ systemie komercyjnym, zawsze, jak podkreśla Dudzińska, kosztem normalnego życia. $Z$ reguły zazwyczaj jedno z rodziców, najczęściej matka, musi zrezygnować z pracy, by móc opiekować się dzieckiem ${ }^{33}$.

Zdaniem Dudzińskiej, sytuację można poprawić, jednak wymaga to pewnych zmian np. w systemie zarządzania oświatą. Jednym z rozwiązań byłaby decentralizacja zadań oświatowych wobec dzieci z niepełnosprawnością, z przekazaniem dzielnicom zadania prowadzenia wszystkich placówek. Wówczas mogłyby one decydować szybciej i adekwatniej do potrzeb w zakresie specjalizacji placówek na swoim terenie ${ }^{34}$. Na terenie całego kraju (poza Warszawą) kształcenie specjalne (i ponadgimnazjalne) pozostaje $\mathrm{w}$ gestii powiatów, pozostałe placówki są w gestii gminy. Może to powodować trudności tak organizacyjne, jak i związane z komunikacją między jednostkami samorządu, a tym samym płynnym i szybkim reagowaniem na

32 Tamże, s. 87-88.

33 Tamże, s. 88.

${ }^{34}$ A. Dudzińska, Wszystko jasne. Dostępność i jakość edukacji dla uczniów niepetnosprawnych $w$ Warszawie, Warszawa 2009, www.wszystkojasne.waw.pl; A. Giza (red.), Edukacja małego dziec$k a$, s. 88; mimo że od powstania Raportu upłynęło pięć lat, placówki specjalne jako jednostki o znaczeniu ponaddzielnicowym pozostają w Warszawie w bezpośrednim nadzorze Biura Edukacji http://edukacja.warszawa.pl/specjalne-potrzeby-edukacyjne [dostęp: 2.10.2015]. 
pojawiające się. Rozwiązaniem mogłoby być np. przekazanie zarządzania wszystkimi typami placówek jednej jednostce samorządu terytorialnego. Łatwiejsze byłoby wówczas elastyczne reagowanie na potrzeby osób z niepełnosprawnością.

Innym problemem jest edukacja przedszkolna na terenach wiejskich. W tym przypadku jedną z kluczowych kwestii jest dostępność. Gminy wiejskie mają zazwyczaj niższe dochody własne (w przeliczeniu na jednego mieszkańca) niż w miastach. Wyłączając gminy w pobliżu największych aglomeracji, pozostałe są zazwyczaj rzadko zaludnione i to $\mathrm{w}$ nich koszty prowadzenia placówek przedszkolnych i dowożenia do nich dzieci są największe. Problemem jest również zazwyczaj niski poziom świadomości rodziców, lokalnych liderów o znaczeniu edukacji przedszkolnej. Przedszkola rzadko kiedy są priorytetem dla samorządów ${ }^{35}$. W połączeniu ze wspomnianymi wcześniej uwarunkowaniami: kosztami opieki przedszkolnej, niskimi dochodami rodzin na terenach wiejskich, złym wizerunkiem przedszkoli i żłobków traktowanych jako „przechowalnie” dla dzieci, trudno dziwić się niskim wskaźnikom udziału dzieci w edukacji przedszkolnej, $\mathrm{w}$ tym szczególnie dzieci z niepełnosprawnością, gdyż $\mathrm{w}$ tym przypadku dodatkowym czynnikiem niesprzyjającym są braki kompetencyjne kadry pedagogicznej.

Szukając rozwiązań, powtórzyć można pojawiające się już refleksje dotyczące pracy na rzecz środowiska rodzinnego dziecka, uświadamiania rodziców i władz lokalnych w zakresie znaczenia roli edukacji przedszkolnej i wczesnego wspomagania rozwoju. Działania te muszą jednak być równoległe ze wsparciem celowym edukacji przedszkolnej, kształcenie kadry pedagogicznej nastawione na pracę w grupie zróżnicowanej, diagnozę i terapię zaburzeń rozwojowych, ale również pracę z dzieckiem zdolnym, o czym często zapominamy utożsamiając specjalne potrzeby edukacyjne $\mathrm{z}$ deficytami rozwojowymi.

\section{BIBLIOGRAFIA}

Deno E., Special education and developmental capital, Exception Children, 1970, 37.

Dudzińska A., Wszystko jasne. Dostępność i jakość edukacji dla uczniów niepetnosprawnych w Warszawie, Warszawa 2009, www.wszystkojasne.waw.pl

Falkowska E., Telusiewicz-Pacak A. (red.), Dzieci w Polsce. Dane, liczby, statystyki, Polski Komitet Narodowy UNICEF, Warszawa 2013.

${ }^{35}$ A. Giza (red.), Edukacja małego dziecka, s. 93. 
Giza A. (red.), Edukacja matego dziecka, standardy, bariery, szanse, Fundacja Rozwoju Dzieci im. Jana Amosa Komeńskiego, Polsko-Amerykańska Fundacja Wolności, Warszawa 2010.

Grzelak P., Kubicki P., Orłowska M., Realizacja badania ścieżek edukacyjnych niepetnosprawnych dzieci, uczniów i absolwentów. Raport końcowy, IBE, Warszawa 2014.

Kossewska J., Wspótczesne modele integracji szkolnej dzieci niepetnosprawnych www.up. krakow.pl/biblio/pliki/kossewska_02.html

Otrębski W., Konefał K., Mariańczyk K., Kulik M.M., Wspieranie rodzin z niepetnosprawnym dzieckiem wyzwaniem dla pracy socjalnej. Badania rodzin z niepetnosprawnymi dziećmi w województwie lubelskim, Europerspektywa Beata Romejko, Lublin 2011.

Sochacka-Kawiecka M., Makowska-Belta E., Milczarek D., Morysińska A., Zielińska D.A., Wtaczajacy system edukacji i rynku pracy - rekomendacje dla polityki publicznej. Raport końcowy, IBE, Warszawa 2015. 